\title{
Seeding Resilient Restoration: An Indicator System for the Analysis of Tree Seed Systems
}

\author{
Rachel J. Atkinson ${ }^{1, *(D)}$, Evert Thomas ${ }^{1}$, Federico Roscioli ${ }^{1,2}$, Jonathan P. Cornelius ${ }^{3,4}$, Rene Zamora-Cristales ${ }^{5}$, \\ Maria Franco Chuaire ${ }^{5}$, Carolina Alcázar ${ }^{6}$, Francisco Mesén ${ }^{7}$, Hariet Lopez ${ }^{8}$, Roberto Ipinza ${ }^{9}$, \\ Pablo J. Donoso ${ }^{10}$, Leonardo Gallo ${ }^{11}$, Victor Nieto ${ }^{12}$, Julio Ugarte ${ }^{13}$, Cuauhtémoc Sáenz-Romero ${ }^{14} \mathbb{D}_{\text {, }}$ \\ Tobias Fremout $^{1,15}$, Riina Jalonen ${ }^{16}$, Hannes Gaisberger ${ }^{17}$, Barbara Vinceti ${ }^{17}$ (D), Michel Valette ${ }^{18}$ (D), \\ Ennia Bosshard ${ }^{19}$, Marius Ekué ${ }^{20}(\mathbb{D})$, Gabriela Wiederkehr Guerra ${ }^{17}$ and Chris Kettle ${ }^{17,19}$
}

check for updates

Citation: Atkinson, R.J.; Thomas, E.; Roscioli, F.; Cornelius, J.P.;

Zamora-Cristales, R.; Franco Chuaire, M.; Alcázar, C.; Mesén, F.; Lopez, H.; Ipinza, R.; et al. Seeding Resilient Restoration: An Indicator System for the Analysis of Tree Seed Systems. Diversity 2021, 13, 367. https:/ / doi.org/10.3390/d13080367

Academic Editor: Orsolya Valkó

Received: 12 July 2021

Accepted: 2 August 2021

Published: 9 August 2021

Publisher's Note: MDPI stays neutral with regard to jurisdictional claims in published maps and institutional affiliations.

Copyright: (c) 2021 by the authors. Licensee MDPI, Basel, Switzerland. This article is an open access article distributed under the terms and conditions of the Creative Commons Attribution (CC BY) license (https:// creativecommons.org/licenses/by/ $4.0 /)$.
1 Bioversity International, Lima 12175, Peru; e.thomas@cgiar.org (E.T.); f.roscioli@cgiar.org (F.R.); t.fremout@cgiar.org (T.F.)

2 Dipartimento di Scienze per l'Economia e l'Impresa, University of Florence, 50121 Firenze, Italy

3 World Agroforestry (ICRAF), Lima 12175, Peru; j.cornelius@cgiar.org

4 School of Marine and Tropical Biology, James Cook University, Douglas, QLD 4811, Australia

5 World Resources Institute (WRI), Washington, DC 20002, USA; rene.zamora@wri.org (R.Z.-C.); Maria.FrancoChuaire@wri.org (M.F.C.)

6 Instituto de Investigación de Recursos Biológicos, Alexander von Humboldt, Bogotá \#15-09, Colombia; calcazar@humboldt.org.co

7 Centro Agronómico Tropical de Investigación y Enseñanza, Cartago, Turrialba 30501, Costa Rica; fmesen@catie.ac.cr

8 Instituto Nacional de Bosques, Ciudad de Guatemala Zona 13, Guatemala; hariet.lopez@inab.gob.gt

9 INFOR, Instituto Forestal, Fundo Teja Norte s/n, Valdivia 091000, Chile; roberto.ipinza@infor.cl

10 Instituto de Bosques y Sociedad, Universidad Austral de Chile, Valdivia 091000, Chile; pdonoso@uach.cl

11 National Institute for Agricultural Technology (INTA), Bariloche 8400, Argentina; leosogalo@gmail.com

12 Corporación Nacional de Investigación y Fomento Forestal (CONIF), Bogotá \#11-54, Colombia; victornieto@conif.org.co

13 Facultad de Ciencias Forestales, Universidad Nacional Agraria, Lima 12175, Peru; julio.ugarte@gmail.com

14 Instituto de Investigaciones sobre los Recursos Naturales, Universidad Michoacana de San Nicolás de Hidalgo (INIRENA-UMSNH), Morelia 58337, Mexico; csaenzromero@gmail.com

15 Division of Forest, Nature and Landscape, KU Leuven, 3000 Leuven, Belgium

16 Bioversity International, Serdang 43400, Malaysia; r.jalonen@cgiar.org

17 Bioversity International, 00054 Rome, Italy; h.gaisberger@cgiar.org (H.G.); b.vinceti@cgiar.org (B.V.); g.wiederkehr@cgiar.org (G.W.G.); C.Kettle@cgiar.org (C.K.)

18 Center for Environmental Policy, Imperial College of London, London SW7 2BX, UK; michel.valette88@gmail.com

19 Department of Environmental Systems Science, Institute of Terrestrial Ecosystems, Ecosystem Management, ETH Zürich, 8092 Zurich, Switzerland; ennia.b@hotmail.com

20 Bioversity International, Yaoundé P.O. Box 2008, Cameroon; m.ekue@cgiar.org

* Correspondence: r.atkinson@cgiar.org

\begin{abstract}
Achieving multi-million-hectare commitments from countries around the world to restore degraded lands in resilient and sustainable ways requires, among other things, huge volumes of tree planting material. Seed systems encompassing all forest reproductive material (e.g., seeds, cuttings, stakes, and wildings), are key to ensuring that sufficient planting material with a diverse range of suitable species, adapted to local conditions and capable of persisting under a changing climate, is available for restoration projects. The ideal structure of a seed system integrates five components: seed selection and innovation, seed harvesting and production, market access, supply and demand, quality control, and an enabling environment. We propose 15 indicators to evaluate these key components and trial them by assessing national seed systems in 7 Latin American countries. We conclude that the indicators enable a straightforward assessment of the strengths and weaknesses of national seed systems, thus assisting governments to identify key areas for improvement and opportunities for horizontal learning.
\end{abstract}


Keywords: Argentina; Chile; Colombia; Costa Rica; Guatemala; Mexico; Peru; diversity; climate change; seed system; forest genetic resources

\section{Introduction}

The United Nations Decade on Ecosystem Restoration (2021-2030) calls for the protection and revival of ecosystems around the world, for the benefit of people and nature. This proclamation was made in response to the global biodiversity and climate crises, and countries around the world have already committed to the restoration of millions of hectares of degraded land [1]. A significant share of these commitments will be achieved through active tree planting [2,3]. With the goal to regain ecological functionality and enhance human well-being across deforested or degraded landscapes [4,5], not only are the quantity and availability of planting material important, but also the quality. High quality material enables provision of the desired ecosystem services and the necessary genetic diversity to persist into the future [6]. The genetic quality of planting material has three main dimensions: (i) ensuring adaptedness to the current and future environmental conditions of a given planting site; (ii) promoting the long-term viability and resilience of restored populations; and (iii) favoring genetically based desirable traits (e.g., straight stems for timber production). The desired quality of planting material will ultimately depend on the objectives and time scales of restoration projects.

At present, the limited availability and accessibility of quality planting material is a constraining factor in restoration programs $[7,8]$. Thus, there is a global need to strengthen seed production and supply systems at the national, regional, and local level. This will ensure that material with a diverse range of suitable species, adapted both to local conditions and capable of persisting over generations under a changing climate, is available. Functional seed systems need to integrate five interlinked components: (i) seed selection and innovation; (ii) seed harvesting and production; (iii) market access, supply, and demand; (iv) quality control; and (v) a favorable enabling environment. The word "seed" is hereby used to refer to seeds, cuttings, stakes, wildlings, and any other form of forest reproductive material (FRM).

Seed selection and innovation. Restoration projects that involve active tree planting should choose species and seed sources that can survive and grow under site-specific conditions in the short term and persist under a changing climate in the longer term $[9,10]$. The species choice should also be aligned with restoration objectives defined by stakeholders and with local people's preferences and needs [11-13]. Generating and sharing knowledge on the most suitable species and seed sources for different planting conditions and restoration objectives is key. This requires the integration of information that includes traditional and local knowledge [14,15], species ecology and functional traits [16,17], climate modeling, genetics and genomics, pilot plantings, and provenance or progeny trials $[6,18]$, etc.

Seed harvesting and production. FRM can be procured from the wild (in situ harvesting of seeds and wildings from natural vegetation, farmland, and managed forests), or from selected material (seed orchards, clonal gardens, and via in vitro propagation) [19]. The material can be used directly in nurseries or stored in seedbanks [20]. Nurseries can play a key role in linking FRM from diverse seed sources to the end user, as well as providing and managing information to enable an informed choice of appropriate FRM. This includes the origin of the material, predicted suitability for a restoration site, and its genetic diversity $[19,21]$. Seed harvesting and production can involve a wide variety of stakeholders, including indigenous and local communities, farmers, private landowners, protected areas, and public and private sector actors [22].

Market access, supply, and demand. In contrast to systems for commercial timber tree species that have existed for 40-50 years in the tropics [23-25], the demand for and supply of native species for restoration are still in their infancy. While FRM for restoration is often produced by projects for their own use [7], the challenge for seed systems lies 
in establishing the cost-effective collection of FRM from different provenances into a nationwide distribution system. This ensures that buyers can have access to FRM that is locally adapted and suitable for future climate conditions $[23,25]$. Seed supply systems for forest restoration include government-centralized models, community-level production with supply facilitated by NGOs, and commercial seed supply (often established with public funding) $[25,26]$. The optimal supply system will depend on political preferences, existing infrastructure and institutional arrangements, as well as available investment.

Ultimately, what is available in a seed supply system will be driven by demand [27]. Demand can be created in multiple ways, but public authorities in particular can play an important role in disseminating knowledge and generating incentives (or disincentives) to align the supply chain to restoration objectives. For example, when restoration is carried out as an obligatory compensation measure for large-scale infrastructure projects, or for carbon credits, via government programs, or privately led initiatives, there is scope for ensuring the optimal selection of FRM. There could also be additional incentives for including species endangered by overharvesting, or habitat destruction.

Quality control. Ensuring the quality of FRM in a seed system is critical for building trust and ensuring that restoration projects are able to meet their objectives [28]. Quality control can be organized in different ways, ranging from regulatory approaches, such as the certification of seeds and other material, to due diligence approaches whereby all actors in the system respect best practice guidelines. Seed characteristics typically considered in quality control relate to germination rates, purity, and phytosanitary standards. For commercially valuable species, a guarantee that the germplasm is from selected or improved FRM is also often included [29]. Other important aspects that are less often included relate to the accurate identification of species and the genetic diversity needed long-term success [30].

Enabling environment. Aside from the technical components outlined above, a suitable enabling environment encompassing political will, legal support and adequate investment in capacity building and research is key to success.

Based on the above criteria, we developed a set of indicators that enables assessment of national tree seed systems for restoration against a model system with the elements needed to provide suitable FRM to projects at scale. We trialed the indicators by evaluating the tree seed systems in seven Latin American countries (Argentina, Chile, Colombia, Costa Rica, Guatemala, Mexico, and Peru) whose joint restoration pledges amount to $16.4 \mathrm{M}$ ha (https: / / initiative20x20.org/ accessed on 20 June 2021). We show how the indicator system enables a straightforward assessment of the strengths and weaknesses of the components that are currently in place, assisting governments in the identification of key areas for improvement as well as opportunities for horizontal learning.

\section{Materials and Methods}

The development of the indicator system was based on information collected from 2 sources: interviews with experts and revision of available information. This allowed us to ascertain both how national seed systems are working and collate opinion and information on an idealized system. Interviews containing 40 questions were carried out with 115 experts from key institutions and organizations in the 7 countries of focus. They included members of the Latin American Forest Genetic Resources Network (LAFORGEN): Argentina $(n=8)$, Chile $(n=10)$, Colombia $(n=36)$, Costa Rica $(n=12)$, Guatemala $(n=19)$, Mexico $(n=14)$, and Peru $(n=16)$. Information from the interviews was enriched with a thorough literature review of published and unpublished work, as well as governmental and other websites in both English and Spanish. All of this information, including the questionnaire, is synthesized in Alcazar et al. [31] and Atkinson et al. [32]. The respondents are acknowledged at the end of this paper and a summary of the seed system in each country is provided in Supplementary Information 1.

Based on an analysis of this information and using the 5 themes described in the introduction as an underlying structure, we developed a streamlined set of indicators 
that covers the key attributes of a national system needed to provide FRM for tree-based restoration and meets the objectives and needs of stakeholders under climate change scenarios. The 5 indicator groups can be summarized as follows:

i. Selection of FRM (indicators 1-4): evaluates the availability of information to ensure that the most appropriate diversity of FRM in terms of species, origin, and intraspecific genetic diversity can be selected;

ii. Harvesting and production (indicators 5-7): evaluates the systems in place for the collection and production of suitable FRM;

iii. Supply and demand (indicators 8-9): evaluates the supply and demand for suitable FRM,

iv. Quality control (indicators 10-12): evaluates whether there are systems in place to ensure that the FRM available for restoration planting meets expected quality standards,

v. Enabling environment (indicators 13-15): evaluates whether the production, supply, and use of suitable FRM for restoration are supported by sufficient human capital, financial mechanisms, and an appropriate legal framework.

Each of the above groups is composed of 2 to 4 indicators, giving a total of 15 indicators. A score is given to each indicator by responding to questions that cover the most important aspects of that indicator (Table 1). Each question has a multiple option answer, with 4 possible answers (0-3). These are presented in Supplementary Information 1 . The scores resulting from each question are standardized using a percentage scale and averaged to give an overall score per indicator.

Table 1. The indicator component titles, underlying indicators, and corresponding questions that make up the set of indicators for the analysis of tree seed systems.

\begin{tabular}{|c|c|c|c|}
\hline Componen & & Indicator & Question \\
\hline \multirow{15}{*}{ 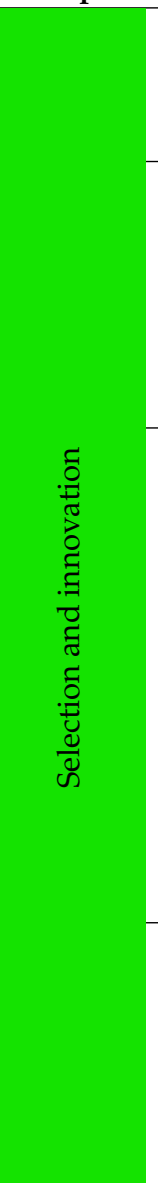 } & \multirow[b]{2}{*}{1} & \multirow{2}{*}{$\begin{array}{l}\text { Different sources of information are used to identify native } \\
\text { species useful for restoration in a variety of ecosystems }\end{array}$} & $\begin{array}{l}\text { Are lists of priority native species for restoration } \\
\text { available for key ecosystems? }\end{array}$ \\
\hline & & & $\begin{array}{l}\text { Are threatened species included in the priority } \\
\text { lists for restoration? }\end{array}$ \\
\hline & \multirow{3}{*}{2} & \multirow{3}{*}{$\begin{array}{l}\text { Research into the effect of climate change on native species } \\
\text { across different ecosystems is used to inform selection of } \\
\text { species and seed sourcing for restoration }\end{array}$} & $\begin{array}{l}\text { Is there research on the effect of climate change } \\
\text { on key ecosystem distribution? }\end{array}$ \\
\hline & & & $\begin{array}{l}\text { Is there research on the effect of climate change } \\
\text { on priority native species distribution? }\end{array}$ \\
\hline & & & $\begin{array}{l}\text { Is there research on the effect of climate change } \\
\text { used to inform planting decisions for } \\
\text { restoration? }\end{array}$ \\
\hline & \multirow{7}{*}{3} & \multirow{7}{*}{$\begin{array}{l}\text { Information on species genetic diversity is used to identify } \\
\text { goal-oriented planting material }\end{array}$} & $\begin{array}{l}\text { Are there provenance trials across the country } \\
\text { for the priority species? }\end{array}$ \\
\hline & & & Are data being collected from these trials? \\
\hline & & & $\begin{array}{l}\text { Are the data being used to inform seed source } \\
\text { choice for restoration? }\end{array}$ \\
\hline & & & Is there research on species population genetics? \\
\hline & & & $\begin{array}{l}\text { Is there research on defining eco-geographical } \\
\text { zones for priority species? }\end{array}$ \\
\hline & & & $\begin{array}{l}\text { Is this information used to define seed transfer } \\
\text { zones? }\end{array}$ \\
\hline & & & $\begin{array}{l}\text { Are there research initiatives developing } \\
\text { improved material for those priority species } \\
\text { used in restoration for productive purposes? }\end{array}$ \\
\hline & \multirow{3}{*}{4} & \multirow{3}{*}{$\begin{array}{l}\text { Suitable information is readily available to inform } \\
\text { stakeholders in their restoration choices }\end{array}$} & $\begin{array}{l}\text { Is suitable information readily available to } \\
\text { stakeholders that helps in species choice for } \\
\text { restoration? }\end{array}$ \\
\hline & & & $\begin{array}{l}\text { Is suitable information readily available on how } \\
\text { to identify the most suitable seed source? }\end{array}$ \\
\hline & & & $\begin{array}{l}\text { Is suitable information readily available on the } \\
\text { difference between wild and selected material? }\end{array}$ \\
\hline
\end{tabular}


Table 1. Cont.

\begin{tabular}{|c|c|c|c|}
\hline Compon & & Indicator & Question \\
\hline \multirow{8}{*}{ 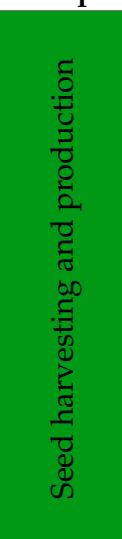 } & \multirow{4}{*}{5} & \multirow{4}{*}{$\begin{array}{l}\text { Seed sources that cover the geographical range of the } \\
\text { priority native species have been identified and are } \\
\text { protected effectively }\end{array}$} & $\begin{array}{l}\text { Have seed sources been identified for the } \\
\text { priority species? }\end{array}$ \\
\hline & & & $\begin{array}{l}\text { Have seed sources been identified for key } \\
\text { ecosystems? }\end{array}$ \\
\hline & & & Do seed sources cover the species range? \\
\hline & & & Are seed sources protected effectively? \\
\hline & \multirow{2}{*}{6} & \multirow{2}{*}{$\begin{array}{l}\text { Improved material is available for those priority species } \\
\text { used in restoration for productive purposes }\end{array}$} & $\begin{array}{l}\text { Is there improved material available for those } \\
\text { priority species used in restoration for } \\
\text { productive purposes? }\end{array}$ \\
\hline & & & $\begin{array}{l}\text { Is improved material available for the key } \\
\text { ecosystems? }\end{array}$ \\
\hline & \multirow[b]{2}{*}{7} & \multirow[b]{2}{*}{$\begin{array}{l}\text { Nurseries are able to produce the priority species adapted } \\
\text { to each ecosystem }\end{array}$} & Are all the priority species being produced? \\
\hline & & & $\begin{array}{l}\text { Are they being produced across each key } \\
\text { ecosystem? }\end{array}$ \\
\hline \multirow{4}{*}{ 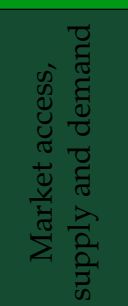 } & \multirow{2}{*}{8} & \multirow{2}{*}{$\begin{array}{l}\text { There is demand for priority native species of suitable } \\
\text { provenance for restoration across targeted ecosystems }\end{array}$} & Is there demand for priority native species? \\
\hline & & & Do people request suitable provenance? \\
\hline & \multirow[b]{2}{*}{9} & \multirow{2}{*}{$\begin{array}{l}\text { There is a network of suppliers able to meet the demand for } \\
\text { priority native species of suitable provenance across } \\
\text { targeted ecosystems }\end{array}$} & Is there a network of suppliers? \\
\hline & & & $\begin{array}{l}\text { Can the network meet demand (access and } \\
\text { quantity) for natives with suitable provenance? }\end{array}$ \\
\hline \multirow{5}{*}{ 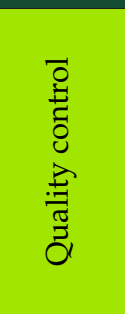 } & \multirow{2}{*}{10} & \multirow{2}{*}{$\begin{array}{l}\text { Measures exist to comply with seed sourcing and } \\
\text { harvesting standards }\end{array}$} & $\begin{array}{l}\text { Does certification cover seed sourcing } \\
\text { (population size, sampling method)? }\end{array}$ \\
\hline & & & $\begin{array}{l}\text { Does certification cover seed harvesting } \\
\text { (material type, permission to collect)? }\end{array}$ \\
\hline & \multirow[t]{2}{*}{11} & \multirow[t]{2}{*}{ Measures exist to comply with seed quality standards } & $\begin{array}{l}\text { Does certification cover production } \\
\text { (phytosanitary conditions, control of origin)? }\end{array}$ \\
\hline & & & Does certification cover improved seeds? \\
\hline & 12 & Quality control measures function as an integrated system & Do these components function as a system? \\
\hline \multirow{13}{*}{ 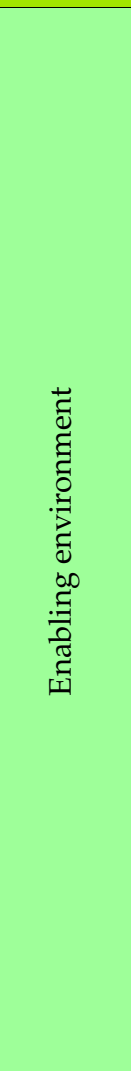 } & \multirow{5}{*}{13} & \multirow{5}{*}{$\begin{array}{l}\text { The seed system is underpinned by appropriate legislation } \\
\text { and regulations applied to native species and implemented }\end{array}$} & $\begin{array}{l}\text { Are adequate regulations being implemented } \\
\text { that support the use of material suitable for } \\
\text { climate change? }\end{array}$ \\
\hline & & & $\begin{array}{l}\text { Are adequate regulations being implemented to } \\
\text { define seed transfer zones? }\end{array}$ \\
\hline & & & $\begin{array}{l}\text { Are adequate regulations being implemented to } \\
\text { protect seed sources? }\end{array}$ \\
\hline & & & $\begin{array}{l}\text { Are adequate regulations being implemented } \\
\text { that provide incentives for the use of native } \\
\text { species? }\end{array}$ \\
\hline & & & $\begin{array}{l}\text { Are adequate regulations being implemented for } \\
\text { a certification system for native species? }\end{array}$ \\
\hline & \multirow{5}{*}{14} & \multirow{5}{*}{ There is appropriate capacity to support a seed system } & $\begin{array}{l}\text { Is there sufficient capacity building for decision } \\
\text { makers? }\end{array}$ \\
\hline & & & $\begin{array}{l}\text { Is there sufficient capacity building for } \\
\text { technicians? }\end{array}$ \\
\hline & & & $\begin{array}{l}\text { Is there sufficient capacity building for } \\
\text { communities? }\end{array}$ \\
\hline & & & $\begin{array}{l}\text { Is there sufficient capacity building for the } \\
\text { general public? }\end{array}$ \\
\hline & & & Is there sufficient capacity building for students? \\
\hline & \multirow{3}{*}{15} & \multirow{3}{*}{$\begin{array}{l}\text { There is sufficient financial support for key research needed } \\
\text { for seed systems }\end{array}$} & $\begin{array}{l}\text { Is there sufficient financial support for baseline } \\
\text { information on priority native species \& key } \\
\text { ecosystems and climate change? }\end{array}$ \\
\hline & & & $\begin{array}{l}\text { Is there sufficient financial support for seed } \\
\text { source identification? }\end{array}$ \\
\hline & & & $\begin{array}{l}\text { Is there sufficient financial support for research } \\
\text { on material production? }\end{array}$ \\
\hline
\end{tabular}


An initial version of the indicators was presented to over 30 regional experts from Latin America via a webinar organized by the World Resources Institute (WRI) in 2017 (Seminario Web sobre Sistemas de Producción y Suministro de Semilla para la Restauración). The system presented here represents an improved version that incorporates the feedback received.

The indicator set was used to score the state of the national seed systems for forest restoration in Argentina, Chile, Colombia, Costa Rica, Guatemala, Mexico, and Peru. Initial scoring was carried out by the first author based on the information presented in Alcazar et al. [31] and Atkinson et al. [32]. The scores were then revised by experts from each of the seven countries who are coauthors on this paper.

\section{Results}

The scores from the set of 15 indicators are presented in Figure 1 and Supplementary Information 1 . The countries show marked differences in current seed systems and strategies, and the following sections highlight the key findings. Further details and references can be found in the country case studies in Supplementary Information 2.

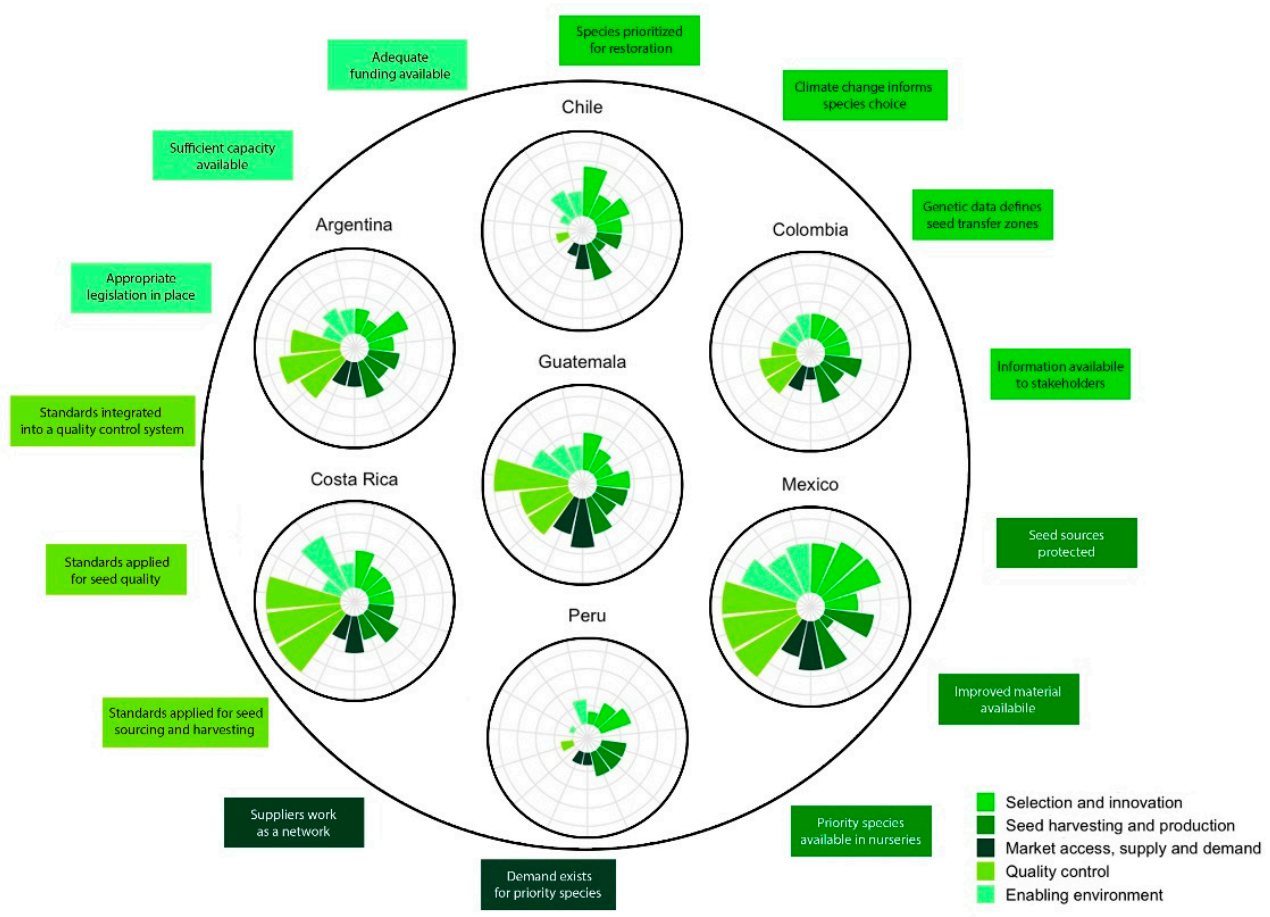

Figure 1. Radar charts illustrating the scores assigned to the 15 indicators for each of the 7 countries analyzed (Argentina, Chile, Colombia, Costa Rica, Guatemala, Mexico, Peru). The results are colorcoded by the 5 components (selection and innovation, seed harvesting and production, market access, supply and demand, quality control, and enabling environment.

\subsection{Selection of FRM (Indicators 1-4)}

While there is a wealth of knowledge on each country's native tree species (indicator 1), this information is often not readily available to restoration practitioners and decision makers, although Mexico, Colombia and Costa Rica have made advances in compiling the information into user-friendly formats (indicator 4).

It is well understood that climate change will significantly alter the distribution of different forest ecosystems and that better connectivity between forest fragments can help species survival. However, countries show an incipient realization that genetic considerations need to be considered if the restored forests are to survive into the future under new climatic conditions. Exceptions include Mexico's official guidelines for restoration and 
Chile's ambitious program to monitor the effect of climate change on different genotypes (indicator 2).

Field trials can help identify species' genotypes that are likely to be suited to future conditions. Mexico and Chile (and to a lesser extent Argentina) have comprehensive networks of actively managed multispecies trials, while Costa Rica, Colombia, and Peru have established trials, but are not maintaining them. These trials concentrate on commercially valuable native species, for which some genetic characterization is usually available. Combined with data from field trials and maps of environmental variables, this information could be used to define seed transfer zones. Mexico, Argentina, and Chile have developed methodologies for defining these zones and have used them for a handful of species. To date, only Mexico has incorporated the concept of seed transfer zones into legislation, and a climate-based seed transfer zoning has been proposed but not yet adopted (indicator 3 ).

\subsection{Harvesting and Production (Indicators 5-7)}

While several countries have identified priority areas for sourcing seed, conservation of tree genetic resources usually relies on the network of state-owned protected areas and private reserves. Exceptions to this include: Guatemala, with an incentives program for people who wish to protect their land as a seed source; Mexico, with a mechanism to ensure the protection of flora and fauna outside of protected areas; and Chile, where seed source protection is integral to the conservation of threatened valuable tree species. Private forestry businesses, seed suppliers, and nurseries may also manage their own seed sources, in situ (indicator 5).

A complementary approach to ensure that FRM is easily available is via establishment of seed orchards from selected wild trees. Mexico has state-funded seed orchards for key native tree species. Other countries have a more fragmented approach with diverse stakeholders managing seed orchards for priority species. Additionally, seed banks can play an important role in the storage and distribution of FRM. In Mexico, the state-run network of seed banks is distributed across the country. In Argentina, seed banks focus on specific genera (mostly native), while in Costa Rica the focus is on commercially valuable (exotic) species.

The identification of superior genotypes has been carried out for commercially valuable native species in Mexico, culminating in the creation of seed orchards. In other countries, superior genotypes have been identified for a handful of native and introduced species, often by the private sector for their own use (indicator 6 ).

It is a challenge to determine the distribution, abundance, or capacity of nurseries in each country for FRM production, since many are temporary or informal and thus go undocumented. For example, in 2017, Chile had 161 registered nurseries producing native tree species; Colombia and Peru on the other hand have no official register, but both have large-scale commercial nurseries producing native species, as well as plenty of restoration projects producing their own material. In Argentina, there is a network of government-run nurseries with at least one central nursery in each province able to produce up to 1 million plants per year for restoration projects. Mexico also has a network of registered nurseries that are established in tandem with government incentives for restoration (indicator 7).

\subsection{Supply and Demand (Indicators 8-9)}

There appears to be little demand for native tree species FRM in restoration plantings. While most countries have some sort of incentives mechanism in place to promote the use of native species in production forestry, there are only few examples in place for restoration activities with other aims. An exception is FONAFIFO, an incentive mechanism based on payments for ecosystem services established in Costa Rica. We did not find any incentives that stipulate the use of site-adapted or climate-proof FRM in restoration programs (indicator 8).

The lack of adequate seed supply in Chile is considered as a major bottleneck for effective ecosystem restoration [33]. This is likely to be true in other countries too. Even for 
commercially valuable species, there is often little selected or improved FRM available at a commercial scale, and demand is often met through importation, while selected native seed is produced by companies for their own use.

Although integrated supply networks do exist for some commercial species, there are only a few examples for native tree species. Exceptions are government-run networks in Argentina and Mexico, and localized examples run by the private sector in Guatemala and Colombia. In Costa Rica seed storage is centralized and small-scale restoration projects are self-sufficient using their own nurseries (indicator 9).

\subsection{Quality Control (Indicators 10-12)}

Many of the countries included here have a government registration system in place for seed collection that requires information about collection locality, type of material, and tree ownership. In Costa Rica, seed certification for commercially valuable tree species includes verification at the seed source before and during harvesting to reduce fraud (indicator 10).

Regulations to ensure seed purity and germination ability are common but are normally only enforced when seed is for export. Argentina ensures that verified improved seed cannot be falsified by sealing containers with a hologram. Elsewhere, improved seed is available from one or a few accredited suppliers, providing quality assurance. All countries studied have registration systems in place for tree nurseries, but they are not all enforced, and only some of the registration processes require a site inspection. It is even rarer to find any quality control at the planting site, except for commercially valuable species. To date, there are only a few cases where FRM can be traced to its origin, and this occurs de facto in project-specific nurseries that source FRM locally (indicator 11).

The two most complete quality control systems that encompass seed sourcing, nursery production, and delivery of FRM to the planting site are in Mexico (law $n^{\circ}$ AA-169-SCFI2014) and Costa Rica (law n ${ }^{\circ}$ 6289). Although the latter is at present only used for commercially valuable exotic timber species, it can be applied to native species (indicator 12).

\subsection{Enabling Environment (Indicators 13-15)}

While the regulatory aspect of seed supply systems is well developed in most countries (particularly in Costa Rica and Argentina), it is applied to production forestry only. In Guatemala, a successful government incentives program including seed production and distribution is focused on native pines for commercial use. In Chile, many of the key regulatory documents for supporting a seed supply system are awaiting approval and implementation.

In all countries, the most notable weakness in the enabling environment is the limited availability of human capital and capacity at all stages of the seed supply system. For example, in Peru, despite the availability of funds for small scale projects, they are often begun and then abandoned (indicator 14). The research capacity in Mexico, Argentina, Chile, and Costa Rica is however well developed, though scientists are often not sufficiently funded to allow for their full potential to be met (indicator 15).

\section{Discussion}

The use of suitable FRM is the backbone for successful active restoration, and a system that links knowledge with production and supply, increasing demand, and quality control can help ensure its use. The set of indicators presented here provides an operational framework through which to determine the readiness of national systems to support successful active restoration projects. It can also be used as a tool to identify gaps and priority areas for strengthening.

We note that the structure and management of tree seed systems for restoration differs among the seven countries studied. In Mexico and Argentina, the systems are underpinned by regulatory frameworks and implemented by public institutions at the state or regional level, while in Guatemala the availability of FRM has to date been driven by government 
incentives provided to individuals. The availability of native species for restoration in Costa Rica, Colombia, Peru, and Chile is fragmented with individuals, companies, or institutions producing FRM for their own use (although activities are often motivated by governmentled initiatives). This contrasts with effective systems for commercial forestry with exotic species in both Costa Rica and Chile, with a focus on high-quality seed production for national use and export in the former, while in the latter forestry from seed to timber is managed by private companies.

While we note that all seven countries had at least some aspects of a functional tree seed system in place, two important gaps were common to all: (i) the limited use of native species diversity in restoration; and (ii) the lack of consideration of the genetic diversity of the FRM used. These aspects have been highlighted as critical for the resilience of restoration plantings under climate change [15,17].

Latin America has an exceptionally high diversity of native tree species [34], and most of the countries studied here are considered as megadiverse [35]. Despite this, very few native species are used in restoration or even in forestry. While the reason may be linked to a lack of knowledge on species propagation or the availability of FRM, these obstacles are not insurmountable. Species diversity is integral to Brazil's Atlantic Rainforest Restoration Pact. The mandatory use of at least 80 species per ha in restoration activities in São Paolo state (Brazil) resulted in an increase in species availability in nurseries, as well as development of a complex network of seed collectors [8] (although it should be noted that a few species dominated plantings [36]). This success story was due to the active involvement of many stakeholders; public and private institutions, governments, companies, the scientific community, and landowners [37]. While use of such a high number of species is highly contextual to the location, ecotone, and restoration intervention, this case study indicates that it is possible to achieve in the region. It should be noted that our analysis did not include information on unregistered temporary nurseries, which are often important and may contain a high diversity of species, especially for conservation-related restoration projects.

Increasing the number of species used in restoration projects requires a concomitant increase in knowledge relating to the sourcing of FRM, propagation and growth requirements, ecology, and ecosystem service provision. As observed in this study, information on species is often widely dispersed and thus not easily accessible to those who require it. There have been some important steps to collate information and make it available online (www.especiesrestauracion-uicn.org (accessed on 22 June 2021), https: //www.diversityforrestoration.org/ (accessed on 22 June 2021), and www.orton.catie. ac.cr/repdoc/a11445e/a11445e.pdf (accessed on 22 June 2021)). The platform www. diversityforrestoration.org (accessed on 23 June 2021) integrates climate modeling, functional trait data, local ecological knowledge, genetics, and information on propagation protocols to assist decision makers and practitioners with the choice of appropriate tree species and seed sources [17]. The knowledge and requirements of local stakeholders is key here, as they are not only directly affected by restoration activities but can also help to identify the most useful and valued species for different purposes [38]. Failure to deliver a broad range of native tree species at scale also undermines not only resilience of restoration efforts to pest and disease outbreaks, but also the potential to deliver multiple societal benefits.

The availability of appropriate FRM has been found to be a limiting factor for many restoration projects across the world $[7,8,33,39]$. This is compounded by the current political climate to meet area or number-based tree planting targets (https:/ / www.plant-for-theplanet.org/en/home (accessed on 23 June 2021), https:/ / www.12tree.de/ (accessed on 23 June 2021)), which may result in the use of whatever material is available [6]. The key to breaking this chain is creating demand for diversity [27]. This will feed back to production and thus strengthen the entire supply system. While demand can be stimulated e.g. through stipulating conditions in incentive mechanisms and regulations, or making access to mitigation funds contingent upon the use of native species and good quality FRM, 
demand from the end user may be more desirable. For this to be achieved, the benefits and know-how of using suitable FRM need to be embraced by practitioners and planners. This will require communicators who can translate scientific concepts to reforestation practitioners, investors, and decision makers. Additionally, business models need to be developed based on native species. Once the demand is there, the commercial forestry sector is often ideally placed to scale up seed supply systems for native species, having already developed efficient, high volume systems of seed sourcing, storage, and production and nationwide networks.

The indicator system illustrated here can be used to monitor the development of country tree seed supply systems, helping to guide the strengthening of key components to ensure that the recent interest and momentum in tree planting results in restoration that can withstand future conditions and provide the ecosystem services we all require. Building on successful experiences and initiatives in the seven countries considered here, we suggest that the following actions could help to increase the use of appropriate FRM in restoration projects, and thus strengthen seed supply systems for restoration:

- Collate information already generated on tree species distribution, ecology, use, and propagation. In every country there is already a wealth of information about tree species that can be very useful for establishing priority species lists for restoration.

- Use practitioner, local and indigenous community knowledge to understand species traits useful for restoration and help identify species that stakeholders value.

- Integrate genetic diversity considerations into plans for forest resilience and adaptation to climate change. The discord between the scale of tree planting actions for climate change and the quality of the planting material needs to be addressed to help ensure that the forests being planted today can adapt to future conditions.

- Strengthen and link research to the main information gaps identified by restoration practitioners and ensure that restoration-relevant information is available in appropriate formats.

- Use information from progeny and provenance trials for seed source selection. Many of the countries have had extensive projects in the past that set up trials for many species across wide areas. To the extent possible past trials should be revived, and new ones established for other native species.

- Spur the development of improved varieties for key commercially important native species.

- Strengthen existing and develop novel approaches to protect in situ seed sources by considering them as valuable economic resources to help motivate their conservation.

- Determine the most effective and socially inclusive ways of scaling up seed collection and propagation of FRM that build on success stories. The commercial forestry sector has experience with this and the lessons learned may help the rapid scaling up of seed supply systems for native species.

- Consider the most cost-effective approach to controlling the quality of FRM of native tree species. Registration and certification methods focus on seed collection and production of selected or improved varieties of commercially valuable species. In contrast, the collection and production of native FRM are often unregulated.

- Stimulate stakeholder demand for appropriate FRM by stipulating conditions in restoration project funding mechanisms. Once the demand is there it will feed back through the production network and thus strengthen the entire seed supply system.

Supplementary Materials: The following are available online at https:/ / www.mdpi.com/article/10 $.3390 / \mathrm{d} 13080367 / \mathrm{s} 1$, Supporting Information 1a: Indicator scores by country expressed as percentage of the total possible score, Supporting Information 1b: Indicator point scores per question by country, Supporting information 2: Case studies of the state of seed systems from seven countries in Latin America. 
Author Contributions: Conceptualization, R.Z.-C., M.F.C., E.T. and J.P.C.; methodology, E.T. and J.P.C.; validation, F.M., H.L., R.I., P.J.D., L.G., V.N., J.U. and C.S.-R.; analysis, R.J.A., E.T. and F.R.; investigation, C.A. and R.J.A.; writing-original draft preparation, R.J.A.; writing-review and editing, E.T., F.R., T.F., R.J., H.G., B.V., M.V., E.B., M.E., G.W.G. and C.K.; funding acquisition, E.T., R.Z.-C. and M.F.C. All authors have read and agreed to the published version of the manuscript.

Funding: This article was produced as a result of research carried out by Initiative $20 \times 20$ partners Biodiversity International, the World Resources Institute (WRI), and the World Agroforestry Centre (ICRAF), financed by the International Climate Initiative (IKI). The German Federal Ministry for the Environment, Nature Conservation Nuclear Safety (BMU) supports this initiative based on a decision adopted by the German Bundestag.

Institutional Review Board Statement: Not applicable.

Data Availability Statement: Supporting reports can be found at and Atkinson et al. [32] https:// www.researchgate.net/publication/324994365_Seed_supply_systems_for_the_implementation_of_ landscape_restoration_under_Initiative_20x20_An_analysis_of_national_seed_supply_systems_in_ Mexico_Guatemala_Costa_Rica_Colombia_Peru_Chile_and_Argentina (accessed on 18 June 2021), and Alcazar et al. [31] https:/ / hdl.handle.net/10568/93071 (accessed on 18 June 2021).

Acknowledgments: The authors would like to acknowledge the contribution of the following: Walter Vergara (World Resources Institute), Gustavo Basil (Instituto Nacional de Tecnología Agropecuaria, Argentina), Norberto Bischoff (Ministerio de Agroindustria, Argentina), César Luis de la Vega (Ministerio de Agroindustria, Argentina), Luis Fernando Fornes Pullarello (Instituto Nacional de Tecnología Agropecuaria, Argentina), Mirta Larrieu (Ministerio de Agroindustria, Argentina), Elizabeth Graciela Verzino (Universidad Nacional de Córdoba, Argentina), Marisa Young (Fundacion Agreste, Argentina), Germán Clasing (CONAF, Chile), Bernando Escobar (Universidad Austral de Chile, Chile), Rolando García (Centro de Biotecnología de los Recursos Naturales, Chile), Maria Paz Molina (INFOR, Chile), Ximena Moncado (CEAZA, Chile), Gustavo Moreno (CONAF, Chile), Mario Paredes (Instituto de Investigaciones Agropecuarias de Chile, Chile), Juan Carlos Pinilla (INFOR, Chile), Mauricio Aguilar (Instituto Humboldt, Colombia), Gloria Arboleda (Jardin Botanico de Cali, Colombia), Jose Ignacio Barrera (Universidad Javeriana REDCRE, Colombia), Luis Ángel Barrera (Viveros especies nativas, Colombia), Rodolfo Caicedo Arias (ICA, Colombia), Zoraida Calle (CIPAV, Colombia), Carlos Julio Castro (CAR Cundinamarca, Colombia), Alejandro Chaparro (Universidad Nacional de Volombia, Colombia), Alvaro Cogollo (Jardin Botanico de Medellin, Colombia), Ricardo Diaz Díaz (Corpoguavio, Colombia), Roy Gonzalez (Instituto Humboldt, Colombia), Rosamira Guillen (Fundación Proyecto Titi, Colombia), Patricia Guzman (Corporación Centro de Estudios Andinos EKIRAWA, Colombia), Jairo Herrrera (Inforagro, Colombia), Carlos Mario Jiménez (Smurfit Kappa Cartón de Colombia, Colombia), Fabio Lozano (Fundación Paisajes rurales, Colombia), Javier Mancera (Ministerio de Ambiente, Colombia), Daniel Manrique (Resnatur, Colombia), Luis Gonzalo Moscoso (FORESTPA SAS, Colombia), Edgar Parrado (Productor material vegetal, Colombia), Laura Victoria Perez (JBB, Colombia), Rosa Elena Ramos Castiblanco (ICA, Colombia), Gina Rodriguez (Ecosistemas Secos de Colombia, Colombia), Javier Rodriguez (CONIF, Colombia), Bibiana Salamanca (Fundacion Bachaqueros, Colombia), Jhon Jairo Sánchez (Ministerio de Ambiente, Colombia), Mauricio Sierra (El Semillero, Colombia), Carolina Sofrony Esmeral (Red de Jardines Botanicos, Colombia), Francisco Torres (Fundación Natura, Colombia), Hernán Ureña (Monterey Forestal, Colombia), Nestor Valero (Corpochivor, Colombia), Fernando Vaquero (Plantar Futuro, Colombia), Orlando Vargas (Universidad Nacional de Colombia, Colombia), Enrique Vega (CONIF, Colombia), Andres Avella (Fundacion Natura, Colombia), Diego Delgado (CATIE, Costa Rica), Bryan Finegan (CATIE, Costa Rica), Milena Gutierrez Leon (Area de Conservacion Guanacaste, Costa Rica), Gustavo Hernandez (Universidad Nacional-INISEFOR, Costa Rica), Jorge Arturo Lobo (Universidad de Costa Rica, Costa Rica), Olman Murillo (Instituto Tecnológico de Costa Rica GENFORES, Costa Rica), Carlos Navarro (Universidad Nacional-INISEFOR, Costa Rica), Gilmar Navarro Chacón (FONAFIFO, Costa Rica), Ariana Quirós (Empresa Forestal MITI S.A. (EARTH), Costa Rica), William Vásquez Carballo (Semillas y Bosques, Costa Rica), Rakan A. Zahawi (Organización para Estudios Tropicales (OET), Costa Rica), Carlos Ramírez (INAB, Guatemala), Rafael Ávila (INAB, Guatemala), Mónica Cifuentes (Vivero Santiago La Cuya, Guatemala), Carlos Cifuentes (Defensores de la Naturaleza, Guatemala), Carlos de León Prera (Productor y Comercializador de Semilla, Guatemala), Guillermo García (Pilones de Antigua, Guatemala), Elmer Gutiérrez (CAMCORE, Guatemala), Selvin Jerónimo (Seed Export, Guatemala), Edgar Martínez (PINFOR-PROBOSQUE de INAB, Guatemala), 
José Vicente Martínez Arévalo (USAC, Guatemala), Silvana Masselli (UVG, Guatemala), Wuilliam Melgar (INAB, Guatemala), Pablo Prado (USAC, Guatemala), Adelso Revolorio (INAB, Guatemala), Luis Reyes (Instituto de Cambio Climático -ICC, Guatemala), Ogden Rodas (FAO, Guatemala), Ebal Sales Sales (Políticas Forestales PFN-INAB, Guatemala), Oscar Valenzuela (FAO, Guatemala), Mártir Vásquez (INAB, Guatemala), Claudia Álvarez Aquino (Instituto de investigaciones forestales, Mexico), Rafael Alvarez Reyes (CONAFOR, Mexico), Alfredo Arciniega Mendoza (CONAFOR, Mexico), Esmeralda Cruz Gutierrez (INIFAB, Mexico), Jean Paul Delgado Percastegui (CONAFOR, Mexico), Yanet Biviana García Cruz (CONAFOR, Mexico), Horacio Paz (Universidad Autónoma de México, Mexico), Neptalí Ramírez-Marcial (El Colegio de la Frontera sur (ECOSUR), Mexico), Virginia Rebolledo Camacho (Universidad Veracruzana, Mexico), Carlos Román Castillo (Centro Nacional de Recursos Genéticos del INIFAP, Mexico), Lorena Ruiz-Montoya (El Colegio de la Frontera sur (ECOSUR), Mexico), Nahum M. Sánchez (Universidad Michoacana de San Nicolás de Hidalgo, Mexico), Christian Wehenkel (Universidad Juarez del Estado de Durango, Mexico), Javier Arce Baca (GIZ, Mexico), Cristina María Cabrera Gil Grados (INIA-Autoridad Nacional de Semillas, Peru), Susana Lourdes Chumbiauca Mateo (INIA-Autoridad Nacional de Semillas, Peru), Eloy Cuéllar Bautista (INIA-Dirección de Productos Agrarios, Peru), Ymber Flores Bendezú (INIA—Sede Pucallpa, Peru), Manuel Guariguata (CIFOR, Peru), Julio Huamaní Arotoma (INIA-Dirección de Extensión agraria, Peru), Walter Wilfredo Ledesma Puppi (INIA-Autoridad Nacional de Semillas, Peru), Lucía Elsa Pajuelo Cubillas (INIA-Autoridad Nacional de Semillas, Peru), Soledad Alicia Porras Jorge (INIAAutoridad Nacional de Semillas, Peru), Mariela Ramírez Sánchez (INIA-Autoridad Nacional de Semillas, Peru), Valentina Robiglio (ICRAF, Peru), Fernando Salvador (Forestec (FORESTSOIL), Peru), Natalia Maravi and Laura Snook (Bioversity International).

Conflicts of Interest: The authors declare no conflict of interest.

\section{References}

1. Brancalion, P.H.S.; Holl, K.D. Guidance for Successful Tree Planting Initiatives. J. Appl. Ecol. 2020, 57, 2349-2361. [CrossRef]

2. Philipson, C.D.; Cutler, M.E.J.; Brodrick, P.G.; Asner, G.P.; Boyd, D.S.; Moura Costa, P.; Fiddes, J.; Foody, G.M.; van der Heijden, G.M.F.; Ledo, A.; et al. Active Restoration Accelerates the Carbon Recovery of Human-Modified Tropical Forests. Science 2020, 369, 838. [CrossRef] [PubMed]

3. Strassburg, B.B.N.; Iribarrem, A.; Beyer, H.L.; Cordeiro, C.L.; Crouzeilles, R.; Jakovac, C.C.; Braga Junqueira, A.; Lacerda, E.; Latawiec, A.E.; Balmford, A.; et al. Global Priority Areas for Ecosystem Restoration. Nature 2020, 586, 724-729. [CrossRef]

4. Chazdon, R.L.; Brancalion, P.H.S.; Laestadius, L.; Bennett-Curry, A.; Buckingham, K.; Kumar, C.; Moll-Rocek, J.; Vieira, I.C.G.; Wilson, S.J. When Is a Forest a Forest? Forest Concepts and Definitions in the Era of Forest and Landscape Restoration. Ambio 2016, 45, 538-550. [CrossRef] [PubMed]

5. IUCN; WRI. A Guide to the Restoration Opportunities Assessment Methodology (ROAM) Assessing Forest Landscape Restoration Opportunities at the National or Sub-National Level; IUCN: Gland, Switzerland, 2014; p. 125.

6. Thomas, E.; Jalonen, R.; Loo, J.; Boshier, D.; Gallo, L.; Cavers, S.; Bordács, S.; Smith, P.; Bozzano, M. Genetic Considerations in Ecosystem Restoration Using Native Tree Species. For. Ecol. Manag. 2014, 333, 66-75. [CrossRef]

7. Jalonen, R.; Valette, M.; Boshier, D.; Duminil, J.; Thomas, E. Forest and Landscape Restoration Severely Constrained by a Lack of Attention to the Quantity and Quality of Tree Seed: Insights from a Global Survey. Conserv. Lett. 2018, 11, e12424. [CrossRef]

8. Dayrell, R.L.C.; Arruda, A.J.; Buisson, E.; Silveira, F.A.O. Overcoming Challenges on Using Native Seeds for Restoration of Megadiverse Resource-Poor Environments: A Reply to Madsen et Al. Restor. Ecol. 2016, 24, 710-713. [CrossRef]

9. Sáenz-Romero, C.; Lamy, J.-B.; Ducousso, A.; Musch, B.; Ehrenmann, F.; Delzon, S.; Cavers, S.; Chałupka, W.; Dağdaş, S.; Hansen, J.K.; et al. Adaptive and Plastic Responses of Quercus Petraea Populations to Climate across Europe. Glob. Chang. Biol. 2017, 23, 2831-2847. [CrossRef]

10. Castellanos-Acuña, D.; Lindig-Cisneros, R.; Sáenz-Romero, C. Altitudinal Assisted Migration of Mexican Pines as an Adaptation to Climate Change. Ecosphere. 2015, 6, art2. [CrossRef]

11. Broadmeadow, M.S.J.; Ray, D.; Samuel, C.J.A. Climate Change and the Future for Broadleaved Tree Species in Britain. Forestry 2005, 78, 145-161. [CrossRef]

12. Doherty, K.D.; Butterfield, B.J.; Wood, T.E. Matching Seed to Site by Climate Similarity: Techniques to Prioritize Plant Materials Development and Use in Restoration. Ecol. Appl. 2017, 27, 1010-1023. [CrossRef] [PubMed]

13. Holl, K.D.; Brancalion, P.H.S. Tree Planting Is Not a Simple Solution. Science 2020, 368, 580. [CrossRef] [PubMed]

14. Douterlungne, D.; Levy-Tacher, S.I.; Golicher, D.J.; Dañobeytia, F.R. Applying Indigenous Knowledge to the Restoration of Degraded Tropical Rain Forest Clearings Dominated by Bracken Fern. Restor. Ecol. 2010, 18, 322-329. [CrossRef]

15. Fremout, T.; Thomas, E.; Gaisberger, H.; van Meerbeek, K.; Muenchow, J.; Briers, S.; Gutierrez-Miranda, C.E.; Marcelo-Peña, J.L.; Kindt, R.; Atkinson, R.; et al. Mapping Tree Species Vulnerability to Multiple Threats as a Guide to Restoration and Conservation of Tropical Dry Forests. Glob. Chang. Biol. 2020, 26, 3552-3568. [CrossRef] 
16. Carlucci, M.B.; Brancalion, P.H.S.; Rodrigues, R.R.; Loyola, R.; Cianciaruso, M.V. Functional Traits and Ecosystem Services in Ecological Restoration. Restor. Ecol. 2020, 28, 1372-1383. [CrossRef]

17. Thomas, E.; Alcazar, C.; Gonzalo Moscoso, L.H.; Vasquez, A.; Fernando Osorio, L.; Salgado-Negret, B.; Gonzalez, M.; ParraQuijano, M.; Bozzano, M.; Loo, J.; et al. The Importance of Species Selection and Seed Sourcing in Forest Restoration for Enhancing Adaptive Potential to Climate Change: Colombian Tropical Dry Forest as a Model. In The Lima Declaration on Biodiversity and Climate Change: Contributions from Science to Policy for Sustainable Development; Convention on Biological Diversity: New York, NY, USA, 2017.

18. Breed, M.F.; Harrison, P.A.; Blyth, C.; Byrne, M.; Gaget, V.; Gellie, N.J.C.; Groom, S.V.C.; Hodgson, R.; Mills, J.G.; Prowse, T.A.A.; et al. The Potential of Genomics for Restoring Ecosystems and Biodiversity. Nat. Rev. Genet. 2019, 20, 615-628. [CrossRef]

19. Pedrini, S.; Gibson-Roy, P.; Trivedi, C.; Gálvez-Ramírez, C.; Hardwick, K.; Shaw, N.; Frischie, S.; Laverack, G.; Dixon, K. Collection and Production of Native Seeds for Ecological Restoration. Restor. Ecol. 2020, 28, S228-S238. [CrossRef]

20. Merritt, D.J.; Dixon, K.W. Seed Availability for Restoration. In The State of the World's Genetic Forest Genetic Resources-Thematic Study Considerations in Ecosystem Restoration Using Native Tree Species; Food and Agriculture Organization: Rome, Italy, 2014; pp. 97-104, ISBN 9789251084694.

21. Vidal, C.Y.; Naves, R.P.; Viani, R.A.G.; Rodrigues, R.R. Assessment of the Nursery Species Pool for Restoring Landscapes in Southeastern Brazil. Restor. Ecol. 2020, 28, 427-434. [CrossRef]

22. Valette, M.; Vinceti, B.; Gregorio, N.; Bailey, A.; Thomas, E.; Jalonen, R. Beyond Fixes That Fail: Identifying Sustainable Improvements to Tree Seed Supply and Farmer Participation in Forest and Landscape Restoration. Ecol. Soc. 2020, 25. [CrossRef]

23. Graudal, L.O.V.; Lillesø, J.-P.B. Experiences and Future Prospects for Tree Seed Supply in Agricultural Development Support: Based on Lessons Learnt in Danida Supported Programmes 1965-2005; Ministry of Foreign Affairs of Denmark: Copenhagen, Denmark, 2007.

24. Brancalion, P.H.S.; Viani, R.A.G.; Aronson, J.; Rodrigues, R.R.; Nave, A.G. Improving Planting Stocks for the Brazilian Atl0antic Forest Restoration through Community-Based Seed Harvesting Strategies. Restor. Ecol. 2012, 20, 704-711. [CrossRef]

25. Lillesø, J.B.L.L.; Graudal, L.; Moestrup, S.; Kjær, E.D.; Kindt, R.; Mbora, A.; Dawson, I.; Muriuki, J.; Ræbild, A.; Jamnadass, R. Innovation in Input Supply Systems in Smallholder Agroforestry: Seed Sources, Supply Chains and Support Systems. Agrofor. Syst. 2011, 83, 347-359. [CrossRef]

26. Nyoka, B.I.; Roshetko, J.; Jamnadass, R.; Muriuki, J.; Kalinganire, A.; Lillesø, J.-P.B.; Beedy, T.; Cornelius, J. Tree Seed and Seedling Supply Systems: A Review of the Asia, Africa and Latin America Models. Small-Scale For. 2015, 14, 171-191. [CrossRef]

27. Perring, M.P.; Erickson, T.E.; Brancalion, P.H.S. Rocketing Restoration: Enabling the Upscaling of Ecological Restoration in the Anthropocene. Restor. Ecol. 2018, 26, 1017-1023. [CrossRef]

28. Frischie, S.; Miller, A.L.; Pedrini, S.; Kildisheva, O.A. Ensuring Seed Quality in Ecological Restoration: Native Seed Cleaning and Testing. Restor. Ecol. 2020, 28, S239-S248. [CrossRef]

29. Pedrini, S.; Dixon, K.W. International Principles and Standards for Native Seeds in Ecological Restoration. Restor. Ecol. 2020, 28, S286-S303. [CrossRef]

30. Kettle, C.; Atkinson, R.; Boshier, D.; Ducci, F.; Dawson, I.; Ekué, M.; Elias, M.; Graudal, L.; Jalonen, R.; Koskela, J.; et al. Priorities, Challenges and Opportunities for Supplying Tree Genetic Resources. Unasylva 2020, 252, 51-61.

31. Alcázar, C.; Villanueva, F.; Home, J.; Lopez, H.; Ipinza, R.; Gallo, L.; Atkinson, R.; Thomas, E. Levantamiento de Línea Base y Escenarios Potenciales de Sistemas de Producción y Suministro de Semillas Forestales Como Apoyo a Los Objetivos de Restauración de Los Países de América Latina Asociados a La Iniciativa 20x20. Biodivers. Int. 2018. [CrossRef]

32. Atkinson, R.; Thomas, E.; Cornelius, J.; Zamora, R.; Franco Chuaire, M. Fit for Purpose Seed Supply Systems for the Implementation of Landscape Restoration under Initiative 20x20: An Analysis of National Seed Systems in Mexico, Guatemala, Costa Rica, Colombia, Peru, Chile and Argentina; World Resources Institute: Washington, DC, USA, 2018.

33. León-Lobos, P.; Bustamante-Sánchez, M.A.; Nelson, C.R.; Alarcón, D.; Hasbún, R.; Way, M.; Pritchard, H.W.; Armesto, J.J. Lack of Adequate Seed Supply Is a Major Bottleneck for Effective Ecosystem Restoration in Chile: Friendly Amendment to Bannister et al. (2018). Restor. Ecol. 2020, 28, 277-281. [CrossRef]

34. Raven, P.H.; Gereau, R.E.; Phillipson, P.B.; Chatelain, C.; Jenkins, C.N.; Ulloa Ulloa, C. The Distribution of Biodiversity Richness in the Tropics. Sci. Adv. 2020, 6, eabc6228. [CrossRef] [PubMed]

35. Ulloa, C.U.; Acevedo-rodríguez, P.; Beck, S.; Belgrano, M.J.; Bernal, R.; Berry, P.E.; Brako, L.; Celis, M.; Davidse, G.; León-yánez, S.; et al. An Integrated Assessment of the Vascular Plant Species of the Americas. Science 2017, 358, 1614-1617. [CrossRef]

36. Cornelius, J.P.; Miccolis, A. Can Market-Based Agroforestry Germplasm Supply Systems Meet the Needs of Forest Landscape Restoration? New For. 2018, 49, 457-469. [CrossRef]

37. Pinto, S.; Melo, F.; Tabarelli, M.; Padovesi, A.; Mesquita, C.; de Mattos Scaramuzza, C.; Castro, P.; Carrascosa, H.; Calmon, M.; Rodrigues, R.; et al. Governing and Delivering a Biome-Wide Restoration Initiative: The Case of Atlantic Forest Restoration Pact in Brazil. Forests 2014, 5, 2212-2229. [CrossRef]

38. Fremout, T.; Gutiérrez-Miranda, C.E.; Briers, S.; Marcelo-Peña, J.L.; Cueva-Ortiz, E.; Linares-Palomino, R.; la Torre-Cuadros, M.; de los, Á.; Chang-Ruíz, J.C.; Villegas-Gómez, T.L.; et al. The Value of Local Ecological Knowledge to Guide Tree Species Selection in Tropical Dry Forest Restoration. Restor. Ecol. 2021, 29, e13347. [CrossRef]

39. Cross, A.T.; Pedrini, S.; Dixon, K.W. Foreword: International Standards for Native Seeds in Ecological Restoration. Restor. Ecol. 2020, 28, S216-S218. [CrossRef] 